\title{
Sustainable Approaches to Waste Management: Regulatory and Financial Instruments
}

\author{
By Maksym Kutsevych ${ }^{1}$, Olena Yara ${ }^{2}$, Liudmyla Golovko ${ }^{3}$, Volodymyr Terpeliuk ${ }^{4}$
}

\begin{abstract}
The aim of this article is to investigate problems of harmonization of Ukrainian waste legislation with the provisions and principles of EU waste policy and development of suggestions for improvement of Ukrainian law. The article provide an overview of EU waste legislation, main EU investment policy and its contributions to municipalities in the area of solid municipal waste management. The ways of ecological modernization of the management of solid municipal waste were investigated. Proposals for implementation of experience of EU member states, which has proved itself in practice, were made.
\end{abstract}

Keywords: EU waste management, EU law, adaptation of Ukrainian legislation to EU standards, financial instruments

\section{EU waste management}

A comprehensive approach to waste management has been introduced in the European Union. In 2018, the European Commission adopted an ambitious circular economy package to support the transition of the EU region to circular economy. In contrast to the traditional, linear economy, in the circular economy, products must be designed and produced so that it would be easy to share, lease, reuse, repair, refurbish and recycle these products while using regenerative resources and renewable energy. The goal is to minimize waste and to keep products and resources in the economy for as long as possible. This win-win approach benefits both the economy and the environment (Ph. Quevauviller, 2005). By the end of 2020, EU Member States have to comply with the requirements set out in the amended Waste Framework Directive and implement new legislation. Key elements of the circular economy package include: a common EU target for recycling $65 \%$ of municipal waste by 2035; a common EU target for recycling $70 \%$ of packaging waste by 2030; separate collection obligations are strengthened and extended to hazardous household waste by the end of 2022, bio-waste - by the end of 2023, textiles - by the end of 2025 (European Comission, 2018).

Currently, EU waste law is one of the most extensively and comprehensively developed part of the environmental acquis that attempts to cover all activities that may

1 $\mathrm{PhD}$., Doctor of Juridical Science, associate professor, deputy dean of the Faculty of Law and associate professor of the Department of Criminal Law and Criminology of the Faculty of Law of Taras Shevchenko National University of Kyiv

${ }^{2} \mathrm{PhD}$., Dean of the Faculty of Law of the National University of Life and Environmental Sciences of Ukraine

${ }^{3}$ PhD., associate professor of the Department of International Law and Comparative Law of the National University of Life and Environmental Sciences of Ukraine

${ }^{4} \mathrm{PhD}$., associate professor of the Department of Pedagogy and Psychology of the Regional Humanitarian and Pedagogical Academy of Taras Shevchenko in Kremenets. 
generate waste. It tends to be highly technical and requires EU Member States to invest in developing waste management infrastructure and waste treatment technologies, and also to develop administrative capacities (Kingston, 2017).

The EU Waste Framework Directive (Directive 2008/98/EC of 19 November 2008 ) is the EU's basic law on waste management. It applies to all types of waste (the exception is nuclear waste and some other specific types of waste) and establishes rules for waste hierarchy, rules for waste management planning, waste collection and treatment, and requires mandatory permitting procedures for recyclers. It is a general requirement of the Waste Framework Directive that, before taking important measures to ensure the disposal and recovery of waste, nationals must restrict the production of waste, in particular by promoting environmentally friendly technologies and products that can be recycled and reused, taking into account existing or potential market for recycled waste. The provisions of the Waste Directive impose on States the obligation to impose effective, proportionate and persuasive sanctions for breaches of waste management requirements.

The aim of the Council Directive 1999/31/EC of 26 April 1999 on the landfill of waste is, by way of stringent operational and technical requirements on the waste and landfills, to provide for measures, procedures and guidance to prevent or reduce as far as possible negative effects on the environment, in particular the pollution of surface water, groundwater, soil and air, and on the global environment, including the greenhouse effect, as well as any resulting risk to human health, from landfilling of waste, during the whole life-cycle of the landfill (Council Directive, 1999). The Directive states that only waste that has been subject to treatment is landfilled. For the placement of the landfill, an appropriate permitting system must be established that will ensure proper control by the state of its functioning, as well as prevent the abuse of the landfill operators and ensure proper monitoring of the landfill operation.

Directive 2010/75/EU of the European Parliament and of the Council of 24 November 2010 on industrial emissions (integrated pollution prevention and control) sets standards for integrated pollution prevention and control, as well as rules and regulations aimed at preventing and reducing emissions into the air, water and land, as well as preventing waste generation in order to achieve a high level of environmental protection in as a whole. The Directive focuses on the permitting system, providing for integrated environmental permits. The essence of an integrated environmental permit is that pollutant emissions into the air, water and soil must be evaluated together. Particular attention in the Directive is given to waste incineration, setting emission limits from waste incineration plants, requirements for such installations, control and monitoring, etc.

Directive 2006/21/EC of 15 March 2006 on the management of waste from extractive industries provides for measures, procedures and guidance to prevent or reduce as far as possible any adverse effects on the environment, in particular water, air, soil, fauna and flora and landscape, and any resultant risks to human health, brought about as a result of the management of waste from the extractive industries (Directive, 2006). The provisions of the Directive establish a number of requirements that facilities for the accumulation of industrial waste must meet in order to prevent large-scale accidents at such facilities. 
As we can see, the European Union has developed detailed legislation in the field of waste management. It contains specific tasks and deadlines for its implementation. In the EU member states a gradual transition to a circular economy is observed.

\section{Adaptation of Ukrainian legislation to EU standards}

The main normative legal acts defining the principles of waste management and priorities in this area are the laws of Ukraine "On Waste" and "On Environmental Protection". According to the Law of Ukraine "On Waste", the main directions of state policy in the field of waste management are: ensuring the complete collection and timely disposal of waste, as well as compliance with environmental safety rules when handling them; minimizing the generation of waste and reducing its risk; ensuring the integrated use of material resources; promoting the maximum possible disposal of waste through direct re-use or alternative use of resource-valuable waste; ensuring safe disposal of nonrecyclable waste by developing appropriate technologies, environmentally friendly methods and means of waste management; organization of control over places or objects of waste disposal in order to prevent their harmful impact on the environment and human health; compulsory accounting of waste based on its classification and certification; creating conditions for the implementation of a separate collection of household waste by introducing socio-economic mechanisms aimed at encouraging the producers of these waste to separate collection; assistance in attracting non-state investments and other extrabudgetary sources of financing in the sphere of waste management. These areas are in line with the requirements of the EU Waste Framework Directive.

The reform of waste management in Ukraine began with the development of a comprehensive National Strategy for Waste Management in Ukraine until 2030, which provides for the solution of a problem situation with the generation, accumulation, storage, processing and disposal of waste, and in particular, the introduction of a separate collection of municipal solid waste and creation of infrastructure for their processing. The Strategy introduces European principles for the management of all types of waste in Ukraine: solid household, industrial, hazardous, agricultural waste, etc. The shortcoming of the Strategy is that it does not envisage the introduction of a tax on packaging and stimulation of electricity production from household waste.

In order to implement the National Strategy for Waste Management, the Cabinet of Ministers of Ukraine adopted National Waste Management Plan until 2030, which lays down the preconditions for adaptation of national legislation to the requirements of EU legislation in the field of waste management and determines sociopolitical, institutional, organizational, technical, regulatory, technological measures in the areas stipulated by the Strategy. The National Waste Management Plan identifies major steps for the next 10 years and also takes into account European approaches to the reform in this area. It was a necessary step, but citizens of Ukraine will be able to see the concrete results of the reform of the sphere of waste management after the approval of the regional waste management plans, which the regions have to develop within the framework of the National Waste Management Plan implementation. These documents 
must determine specific needs of regions in order to create a new infrastructure for the processing, recycling and disposal of waste. It must include a detailed analysis of the current situation of waste management, as well as a list of specific measures for the reduction of waste, its processing and reuse.

The first steps in reforming the industry have already been made, but it is necessary to adopt sectoral laws that will allow introduction of a new model of waste management in Ukraine, providing for prevention and reuse of waste. Now the bill on waste management is in the final stages of approval. The reform proposed by the Government in the field of waste management provides for the introduction of the principles of a circular economy and extended producer responsibility, which have to encourage businesses to minimize waste generation and increase waste recycling, and also introduces a five-step waste management hierarchy that operates in the European Union. The purpose of the bill is as follows: introduction of household and other waste management as a resource for sustainable development of the circular economy; determination of legal, organizational, economic fundamentals and control mechanisms to ensure comprehensive protection of human health and the environment by introducing a waste hierarchy; prevention of negative consequences from operations with household and other wastes, facilitation of their reuse and restoration as secondary raw materials, chemicals and energy resources aimed at overcoming energy insufficiency; keeping records of household and other waste; implementation of measures promoting the re-use of products and preparation for reuse of household and other waste, the use of economical tools for re-use of products; replacing the use of primary energy resources; implementation of economically sound tariffs; implementation of the extended producer responsibility principle and the polluter pays principle to cover the costs of managing household and other waste by their owners; implementation of clear classification of household and other waste; the introduction of a system of effective environmental taxes that will stimulate the prevention of the generation of household and other wastes and make landfills as economically viable as possible (Draft Law, 2019). However, even when progressive areas of waste management are identified, the problem of low technological and innovation levels and the lack of economic incentives for the development of waste recycling (privileges, special taxation, etc.) remain unresolved.

The implementation and operation of these standards requires significant investments in the field of household waste management, starting with the organization of separate sorting and ending with the construction of waste processing and incineration plants (Shkurti, 2019; Ladychenko, 2018, Shulga, 2019; Gulac, 2019, Krasnova, 2019). The need for a comprehensive approach to the issue of waste management is caused by the need to overcome the critical environmental situation caused by waste (Golovko, 2019; Hubanova, 2017). The current realities of waste management in Ukraine indicate that the latter is focused not on the prevention of waste generation, their reuse, recycling, but on the disposal of waste at landfills, which remains the dominant way of waste management.

Draft Law № 4835-d on stimulating the use of household waste as an alternative energy source has been developed (Draft Law, 2019). At the same time the draft law contradicts Ukraine's international obligations, in particular, the Paris Agreement ratified by Ukraine regarding the reduction of carbon dioxide emissions into the atmosphere, 
since a decision is made to incinerate household waste without approximating Ukrainian legislation to EU Directives № 2008/98/EU on waste and 2010/75/EU on industrial emissions, which contain detailed requirements for the implementation of waste incineration processes. The draft law proposes to attribute household waste to alternative energy sources and to set a "green tariff" for electricity generated from the incineration of such waste. In the European Union the priority is given to the prevention of waste generation, separate collection and processing (recycling) and financial support (from the $\mathrm{EU}$ and from individual states) is directed to those operations that are in accordance with the hierarchy of priorities for waste management. Also the draft law contains significant corruption risks, since it obliges business entities to conclude agreements on the collection, disposal or burial of household waste with the executor of household waste management services, which will be determined on a non-competitive basis by the local government in the relevant territory. At the same time, such a performer which will become a monopolist in this territory will have the opportunity to set unreasonably high prices for services for the disposal of household waste (Ecobusiness group, 2019).

Law of Ukraine "On Housing and Communal Services" of 11.09.2017 made changes to the Law of Ukraine "On Waste", as a result of which the latter contains a provision that owners, tenants and users of sources of household waste generation should conclude agreements with a service provider on the collection of household waste and provide separate collection of household waste. This was a significant step in the implementation of the European experience at the national level. However, separate sorting of waste due to the lack of an information campaign among the population and adequate organizational and material support is in practice carried out at an inadequate level.

In Ukraine responsibility for violation of the waste law must be strengthened. According to the Code on Administrative Offenses violation of waste management requirements during collection, transportation, storage, treatment or disposal of waste by physical persons entails a fine from about EUR 2.8 to EUR 28. If the offense was committed by an official the fine is from about EUR 28 to EUR 56. Such fines cannot be considered effective and do not help to prevent violation of the waste law. Moreover, these penalties are rarely imposed on the offender.

Increasing penalties for breaches of waste legislation are also observed in EU Member States. For example, in the Czech Republic, according to the new draft law on waste a fine of EUR 364 to EUR 36353 may be imposed on natural persons for breach of waste legislation and EUR 908053 for legal persons (Ministry of environment, 2019).

Also, it is necessary to supplement the Code of Ukraine on Administrative Offenses with an article which provides for liability for the disposal of household waste in improper places. This should help to reduce unauthorized landfills.

\section{Financing of Waste Management Activities}

EU Member States already have well-proven waste processing technologies and a balanced system of financing for this sector of the economy. Cohesion policy has helped the new EU member states to implement an environmental modernization of the solid waste management system. Cohesion Policy envisages the creation of hundreds of 
thousands of projects including in the sphere of waste management across the EU to reduce regional disparities (Fratesi, 2017). Cohesion Policy had succeeded in reducing disparities among the regions of the European Union (Agovino, 2016). Municipal waste management problems were subject of Operational Programme Infrastructure Environment which operated with funding specially aimed at improvement of waste handling in general, especially to reduce the share of landfilled waste. Current programming period 2014-2020 is not yet at the end, however, new EU member states have already contracted significant amount of support offered by the EU Cohesion Policy (Smékalová, 2018). The projects implemented in this case by the municipalities, unions of municipalities and various corporations founded and owned by the municipalities are mostly focused on waste separation where particular attention has been paid to biological waste from households. These projects aim mostly at handling this type of waste by means of composting directly within the households and the investment mostly include purchase of necessary containers to store this type of waste during the process of composting. Other than that the projects were aimed at improving systems for waste separation in general, including provision of more containers to distribute through the municipalities involved. Several projects were oriented at recultivating former landfills and finally emergence of new re-use centres across the involved municipalities (Smékalová, 2019).

EU financial assistance to Ukraine is aimed at improving the Ukrainian system of radioactive waste management. On November 21, 2018 the European Union launched a project "Determination of the forms of waste providing safe processing, storage and disposal of problem radioactive waste stored at Ukrainian nuclear power plants" aiming the safe management of radioactive waste in Ukraine. The amount of the project is EUR 950000 . The main purpose of this 3-year project is to provide Ukrainian partners with the experience and opportunities to effectively implement modern technologies and to design appropriate facilities for the safe and cost-effective treatment and further disposal of radioactive waste currently accumulated and stored in Zaporizhzhya, Rivne, Yuzhno-Ukrainska, and the Chornobyl nuclear power plants. The beneficiaries of the project are the Ministry of Energy and Coal Industry of Ukraine, represented by National Atomic Energy Generating Company "Energoatom" and State Exclusion Zone Management Agency of Ukraine (The EU has launched a project ..., 2018).

As Ukraine is not a member of the EU and is not covered by a cohesion policy (Funta, 2016; Klimek, 2017; Golovko, 2017), the modernization of the solid waste management system is financed primarily from the local budgets and state budget (Zicha, 2019; Vitiv, 2016). Most of the funds are spent on the construction and reconstruction of landfills and renovation of special vehicle fleet. Thus, in 2019, the total amount of funds spent in the sphere of solid waste management was UAH 1106153000 (EUR 37727 000), of which UAH 180965000 (EUR 6172067 000) were spent on the construction of new landfills, UAH 129989000 (EUR 4433458 000) were spent on the reconstruction of the existing landfills, UAH 470064000 (EUR 16032 000) were spent on the renovation of special vehicle fleet, UAH 142131000 (EUR 4848 000) were spent on renovation of container fleet, on other expenses - UAH 183004000 (EUR 6242 000) (Ministry of Development ..., 2020). 
However, there are a number of disadvantages in the financing system. Budget programs in the field of waste management are mainly aimed to ensure the rational use and storage of production and household waste. At the same time the following conclusion was drawn from the results of the audit of the efficiency of the use of the state budget funds in the sphere of household waste management system, conducted by the Accounting Chamber of Ukraine: the presence of an institutional problem, including problems of state planning, late decision-making at the stage of planning and approval of relevant activities and projects, poor preparation of planning documents; the measures implemented did not have a qualitative impact on solving the problems of household waste management and improving the implementation of public policy in this area; there is no systematic control over the use of budget funds, as well as their economic efficiency (Accounting Chamber of Ukraine, 2018). It is necessary to evaluate the effectiveness of programs. Programs should be aimed at limiting or eliminating the negative impact on the environment and the population from municipal solid waste, storage, saving and restoration of natural resources and environmental elements (land, water, air).

According to the Law on Waste, in Ukraine the financing of waste management activities is provided at the expense of the waste producers and their owners. Funds of local budgets, environmental funds, voluntary contributions of enterprises, institutions, organizations, citizens and their associations, the state budget of Ukraine may be used to finance these activities. At the same time, while defining the payer of services of the removal of household waste, Ukrainian legislation does not determine the payer of services of their processing (treatment) and disposal which is a shortcoming. Another disadvantage is that in Ukraine there are no Methodological recommendations on the application of the procedure for setting tariffs for services of the collection of household waste developed according to European standards (those that existed expired in 2009).

\section{Conclusions}

Nowadays, the household waste management system in Ukraine is inefficient, resource-intensive, and does not prevent the negative impact of waste on the environment and public health. This contradicts the legislatively defined goals and directions of state policy in this area. In Ukraine it is necessary to create a stable legislative framework for waste management which will support the transition from a linear economic model to a circular economy. The circular economy needs to be included in the strategic documents of national and regional level with clear and longterm objectives. In order to promote circular economy specific support programs and measures must be developed and implemented. Analysis of existing planning documents at the national level (National Waste Management Strategy in Ukraine until 2030) and at the local level (regional solid waste management programs) showed poor preparation of planning documents (they are general, do not have clear targets and terms for their implementation, resources of funding and control mechanisms).

It is necessary to create appropriate waste management infrastructure at the local level, improve collection of waste and increase the quality and quantity of waste recycling. In order to achieve these goals it is needed to optimize the distribution and use 
of containers for separate collection of waste, provide financial support for the opening of recycling yards and sorting stations in settlements.

\section{References}

Accounting Chamber of Ukraine. Report on the results of the audit of the implementation of the household waste management system and the efficiency of the use of the state budget funds in this area. (2018). Retrieved from: http://rp.gov.ua/upload-files/Activity/Collegium/2017/221_2017/Zvit_22-1_2017.pdf

Agovino, M., Casaccia, M., \& Crociata, A. (2016). The impact of European Regional Development Fund on separate waste collection: Evidence from Italian regions. Environmental Science \& Policy, 61, 97107.

Council Directive 1999/31/EC of 26 April 1999 on the landfill of waste, OJ L 182, 16.7.1999, p. 1-19

Directive 2006/21/EC of the European Parliament and of the Council of 15 March 2006 on the management of waste from extractive industries and amending Directive 2004/35/EC - Statement by the European Parliament, the Council and the Commission, OJ L 102, 11.4.2006, p. 15-34

Draft Law № 2020 "On Management of Household and Other Waste". (2019). Retrieved from: http://w1.c1.rada.gov.ua/pls/zweb2/webproc4_1?pf3511=66998

Draft Law № 4835-d "On stimulating the use of household waste as an alternative energy source". (2019). Retrieved from: http://w1.c1.rada.gov.ua/pls/zweb2/webproc4_1?pf3511=62379

Ecobusiness group. Conceptual shortcomings of the draft Law № 4835-e: the position of business associations. (2019). Retrieved from: http://ecolog-ua.com/news/konceptualni-nedoliky-proektuzakonu-no-4835-d-pozyciya-biznes-asociaciy

European Comission. Circular Economy. (2018). Retrieved from: https://ec.europa.eu/environment/circular-economy/

Fratesi, U., \& Wishlade, F. G. (2017). The impact of European Cohesion Policy in different contexts. Regional Studies, 51(6), 817-821. Retrieved from: http://doi.org/10.1080/00343404.2017.1326673

Funta, R., Golovko, L., Juriš, F. (2016). Európa a európske právo. Bratislava: Iris.

Golovko, L. (2017) Implementation of EU Water Policy in Ukraine: Problems and Perspectives. Proceedings of the 8th International Scientific Conference Rural Development, 605-610.

Golovko, L., Yara, O., Kutsevych, M., Hubanova, T. (2019). Environmental Policy Integration in Ukraine and the EU. European Journal of Sustainable Development, Volume 8, № 3, 221-227.

Gulac, O., Dubchak, L., Iarmolenko, I., Yanchuk, J. (2019). Cooperation of Ukraine and the European Union in the ecological sector: directions and prospects. European Journal of Sustainable Development, Volume 8, № 1, 22-30.

Hubanova, T., Deineha, M., Yara, O. Socio-economic and legal aspects of environmental crime in Ukraine. Baltic Journal of Economic Studies, 2017, № 5. Vol. 3, 276-280.

Kachur, V., Protosavitska, L., Zasukha, L., Golovko L. (2020). The Role of Legal Culture in Maintaining Social Stability and Countering Separatist Movements: Case of Ukraine. European Journal of sustainable development, Volume 9, № 1, 294-299.

Kingston, S., Heyvaert, V., Čavoški, A. European Environmental Law. Cambridge: Cambridge University Press, 2017, p. 489-490.

Klimek, L. (2017). Mutual Recognition of Judicial Decisions in European Criminal Law. Cham: Springer.

Krasnova, Yu.A., Deineha, M.A., Honcharuk, L.Yu., Svyatchenko, L.O. Ecological court as the guarantee of protection of rights of human and citizens. Bulletin of NAS RK, 2019, № 4, 185-191

Ladychenko V., Melnychuk O., Golovko L., Burmak O. (2020). Waste Management at the Local Level in the EU and Ukraine. European Journal of Sustainable Development, Volume 9, № 1, 329-329.

Ladychenko, V., Golovko L. (2018). The Right to Access to Environmental Information in Ukraine and the EU. European Journal of sustainable development, Volume 7, № 3, 455-459.

Ladychenko, V., Melnychuk, O., Yara, O., Kanaryk J. (2019). International Mechanism of the Environmental Information Access and Cooperation Framework for Climate Change Protection. European Journal of Sustainable Development, Volume 8, № 4, 131-139. 
Ladychenko, V., Yara, O., Uliutina, O., Golovko, L. (2019). Environmental Liability in Ukraine and the EU. European Journal of Sustainable Development, Volume 8, № 2, 261-267.

Law of Ukraine "On Waste". (1998). Bulletin of the Verkhovna Rada of Ukraine (BB), 1998, № 36-37, p.242.

Ministry of Development of Communities and Territories of Ukraine. Status of the sphere of household waste management in Ukraine in 2019. (2020). Retrieved from: https://www.minregion.gov.ua/napryamki-diyalnosti/zhkh/terretory/stan-sfery-povodzhennyaz-pobutovymy-vi/

Ministry of environment The draft law on waste № 708 . (2019). Retrieved from: https://www.mzp.cz/cz/navrh_zakona_o_odpadech

$\mathrm{Ph}$. Quevauviller. (2005). Groundwater monitoring in the context of EU legislation: reality and integration needs, Journal of Environmental Monitoring, 7, 98-102.

Shkurti, A. (2019). Analysis of the Western Balkans power market prices within the entso-e framework. European Journal of Sustainable Development, Volume 8, № 1, 229-236.

Shulga, I., Kurylo, V., Gyrenko, I., Savych, S. (2019). Legal Regulation of Energy Safety in Ukraine and the European Union: Problems and Perspective. European Journal of Sustainable Development, Volume 8, № 3, 439-447.

Smékalová, L. (2018). Evaluating the cohesion policy: targeting of disadvantaged municipalities. Administratie si Management Public, (31), pp. 143-154. Retrieved from: http://www.ramp.ase.ro/en/_data/files/articole/2018/31-10.pdf

Smékalová, L. (2019). Support of the Municipal Waste Management by European Union Cohesion Policy, EU environmental policy and law and their implementation in Ukraine's legal system: Proceedings of the International Scientific and Practical Conference (May 16, 2019, Kyiv, Ukraine), 33-35.

The EU has launched a project for the safe management of radioactive waste in Ukraine. (2018). Retrieved from: https://www.ukrinform.ua/rubric-economy/2584587-es-rozpocav-v-ukraini-proekt-dlabezpecnogo-povodzenna-z-radioaktivnimi-vidhodami.html

Vitiv, V. (2016). Information rights as part of the fourth generation of human rights, Scientific Papers of the Legislation Institute of the Verkhovna Rada of Ukraine, 5, 22-26.

Yara, O., Uliutina, O., Golovko, L., Andrushchenko, L. (2018). The EU Water Framework Directive: Challenges and Prospects for Implementation in Ukraine. European Journal of Sustainable development, Volume 7, № 2, 175-182.

Zicha, J., Golovko, L. (2019). Legislation of the European Union Related to Municipal Waste and its Reflection in the Association Agreement with Ukraine, Human. Law. Environment, Volume 10, № 14, 180-186. 